\title{
ІНФОРМАЦІЙНИЙ АНАЛІЗ ДЕНТАЛЬНОЇ ІМПЛАНТАЦІЇ У ВІЙСЬКОВОСЛУЖБОВЦІВ ІЗ ВТОРИННОЮ АДЕНТІЄЮ ТА РЕКОМЕНДАЦІї ЩОДО ІІЇ ЛІКУВАННЯ
}

\author{
М. 3. Лищишин, В. О. Пономаренко, \\ В. В. Коваленко ${ }^{1}$ М. М. Угрин ${ }^{2}$ \\ Центральна стоматологічна поліклініка Міністерства оборони України \\ 'Українська військово-медична академія \\ ${ }^{2}$ Національна спілка стоматологів
}

\begin{abstract}
У статті на основі статистичного аналізу інфрормації про дентальну імплантацію у військовослужбовців із вторинною адентією проведено аналіз результатів лікування та на основі узагальнення результатів обґрунтовано рекомендації щодо вдосконалення лікування. Для дослідження розроблено класифрікацію показів до дентальної імплантації у військовослужбовців Збройних Сил України, що базується на їх розподілі за соціальними та клінічними параметрами. За соціальними параметрами визначено такі групи: військовослужбовці 3 наслідками бойових ушкоджень щелепно-лицевої ділянки; військовослужбовці, які отримали бойові поранення інших анатомічних ділянок; інші військовослужбовці. За клінічними параметрами - військовослужбовці 3 вторинною адентією, заміщення десектів у яких незнімними ортопедичними конструкціями можливе лише при використанні дентальної імплантації; військовослужбовці 3 вторинною адентією, заміщення дефектів у яких незнімними конструкціями можливе як класичними мостоподібними протезами, так і при використанні дентальної імплантації (метод вибору); військовослужбовці з вторинною адентією, проведення дентальної імплантації у яких можливе лише після проведення додаткових передімплантаційних кістково-пластичних утручань. При цьому порядок лікування представлено за етапами. За результатами досліджень доведено, що система медичної реабілітації учасників бойових дій із вторинними дефектами зубних рядів потребує більш детального дослідження та вдосконалення.
\end{abstract}

Ключові слова: військовослужбовці, вторинна адентія, дентальна імплантація, система медичної реабілітації, соціальні та клінічні параметри.

\section{ANALYSIS OF DENTAL IMPLANTATION IN SERVICEMEN WITH SECONDARY ADENTIA AND RECOMMENDATIONS FOR ITS TREATMENT}

\author{
M. Z. Lyczichyn, V. O. Ponomarenko, \\ V. V. Kovalenko', M. M. Ugrin ${ }^{2}$ \\ Central Dental Clinic of the Ministry of Defense of Ukraine \\ ${ }^{1}$ Ukrainian Military Medical Academy \\ ${ }^{2}$ National Union of Dentists
}

Background. In the article on the basis of statistical analysis of information on dental implantation in servicemen with secondary adentia the analysis of treatment results is carried out and on the basis of generalization of results recommendations on improvement of treatment are substantiated.

Materials and methods. IThe object of the study is the medical rehabilitation of combatants with secondary defects of the dentition. The following research methods were used during the research: observation, generalization, statistical analysis, synthesis.

Results. Studies conducted at the Central Dental Clinic of the Ministry of Defense of Ukraine during the practical treatment of military suggest that in 2015-2020, dental implants were performed in more than 700 patients with secondary adentia, among servicemen involved in hostilities in eastern Ukraine. A total of 3598 dental implants were installed. At the same time, the number of servicemen among the participants in the war in eastern Ukraine who need dental implants is constantly growing and today is more than two thousand military.

The order of complex treatment of patients with secondary adentia included three successive stages: diagnostic, surgical, orthopedic. These stages are interrelated and different in terms of duration over time. These stages are different in duration. The most difficult is the second stage, the duration of which can reach up to 6 months.

According to research, the largest number of servicemen with secondary adentia, replacement of defects in which nonremovable orthopedic structures is possible only with the use of dental implants is $76 \%$ for the selected evaluation period, which indicates the priority of this treatment.

Conclusions. Thus, the order of complex treatment of dental implantation in military with secondary adentia is considered, as well as indicators of the number of servicemen who were treated using the proposed classification. It is determined that the restoration of masticatory function caused by tooth loss is an urgent problem of dentistry.

Key words: servicemen, secondary adentia, dental implantation, medical rehabilitation system, social and clinical parameters.

(c) М. З. Лищишин, В. О. Пономаренко, В. В. Коваленко, М. М. Угрин 


\title{
ИНФОРМАЦИОННЫЙ АНАЛИЗ ДЕНТАЛЬНОЙ ИМПЛАНТАЦИИ У ВОЕННОСЛУЖАЩИХ С ВТОРИЧНОЙ АДЕНТИЕЙ И РЕКОМЕНДАЦИИ ПО ЕЕ ЛЕЧЕНИЮ
}

\author{
Н. С. Лищишин, В. А. Пономаренко, \\ В. В. Коваленко ${ }^{1}$, М. М. Угрин ${ }^{2}$ \\ Центральная стоматологическая поликлиника Министерства обороны Украины \\ 'Украинская военно-медицинская академия \\ ${ }^{2}$ Национальный союз стоматологов
}

\begin{abstract}
В статье на основе статистического анализа информации о дентальной имплантации у военнослужащих с вторичной адентией проведен анализ результатов лечения и на основе обобщения результатов обоснованы рекомендации по совершенствованию лечения. Для исследования разработана классификация показаний к дентальной имплантации у военнослужащих Вооруженных Сил Украины, которая базируется на их распределении по социальным и клиническим параметрам.

По социальным параметрам определены следующие группы: военнослужащие с последствиями боевых повреждений челюстно-лицевой области; военнослужащие, получившие боевые ранения других анатомических участков; другие военнослужащие.

По клиническим параметрам - военнослужащие с вторичной адентией, замещение десектов у которых несъемными ортопедическими конструкциями возможно лишь при использовании дентальной имплантации; военнослужащие с вторичной адентией, замещение дефектов у которых несъемными конструкциями возможно как классическими мостовидными протезами, так и при использовании дентальной имплантации (метод выбора); военнослужащие с вторичной адентией, проведение дентальной имплантации у которых возможно лишь после проведения дополнительных предимплантационных костно-пластических вмешательств. При этом порядок лечения рассмотрено по этапам.

По результатам исследований доказано, что система медицинской реабилитации участников боевых действий с вторичными десректами зубных рядов требует более детального исследования и совершенствования.
\end{abstract}

Ключевые слова: военнослужащие, вторичная адентия, дентальная имплантация, система медицинской реабилитации, социальные и клинические параметры.

Вступ. Відомо, що охорона здоров’я — пріоритетний напрям діяльності суспільства та держави, один із головних чинників виживання та розвитку народу України [1]. В сучасних умовах відновлення миру на основі міжнародного права, територіальної цілісності та державного суверенітету на тимчасово окупованих територіях Донецької та Луганської областей України важливим аспектом являється охорона здоров'я й організація лікування військовослужбовців - учасників бойових дій.

Відновлення функції жування, що виникла внаслідок втрати зубів, є актуальною проблемою стоматології. Ефективним методом лікування таких пацієнтів являється дентальна імплантація [2].

Аналіз результатів медичного огляду військовослужбовців, які брали та беруть участь у веденні бойових дій на сході України дозволив виявити достатньо високий рівень бойового травматизму та стоматологічної захворюваності серед них. Близько 27 \% із числа тих, хто пройшли медичний огляд потребують зубного протезування [3, 4].
Зазначимо, що кількість військовослужбовців учасників бойових дій на сході України, які потребують дентальної імплантації постійно зростає. Станом на 01.01.2021 року такої медичної допомоги очікувало більше 2 тисяч осіб. Відповідно виникає проблема щодо забезпечення реалізації права на реабілітацію та лікування зазначеної категорії пацієнтів із вторинною адентією.

В сучасних літературних джерелах існує небагато публікацій, присвячених досвіду використання дентальних імплантатів у комплексі медичної реабілітації військовослужбовців. Власний же досвід свідчить про високу ефективність застосування дентальної імплантації у комплексі медичної реабілітації ветеранів війни $[5,6]$.

Встановлено, що основною причиною втрати зубів українськими військовослужбовцями $€$ низький рівень їхнього стоматологічного здоров'я. Ця проблема існує й в інших арміях світу. Наприклад, у 66 \% хорватських військовослужбовців наявні проблеми зі стоматологічним здоров'ям, що суттєво 
знижує їх бойову готовність [7]. Подібна проблема існує й в австралійській армії [8]. Слід зазначити, що відповідно до діючого STANAG 2466 (Dental Fitness Standards for Military Personnel and a Dental Fitness Classification System) військовослужбовці 3 таким станом стоматологічного здоров'я в зону проведення воєнних дій не допускаються [9, 10, 11].

Для досягнення визначеної мети необхідне вирішення низькі наукових і практичних завдань, а саме: проведення аналізу результатів дентальної імплантації у військовослужбовців; аналізу стану системи забезпечення дентальної імплантації, розроблення класифікації показів до дентальної імплантації у військовослужбовців, обгрунтування рекомендацій про вдосконалення існуючої системи тощо. Розглянемо частину з цих актуальних завдань.

Мета дослідження: обгрунтування рекомендацій до вдосконалення дентальної імплантації при лікуванні вторинної адентії у військовослужбовців.

Матеріал і методи дослідження. Об'єкт дослідження - медична реабілітація учасників бойових дій із вторинними дефектами зубних рядів. Предмет дослідження - дентальна імплантація в комплексі лікування українських військовослужбовців із вторинною адентією. Дослідження проводились у Центральній стоматологічній поліклініці Міністерства оборони України під час практичного лікування військовослужбовців. У 2015-2020 роках дентальну імплантацію проведено більш ніж 700 пацієнтам із вторинною адентією із числа військовослужбовців - учасників бойових дій на сході України. Загалом їм встановлено 3598 дентальних імплантатів. Для проведення досліджень використано такі методи: спостереження, узагальнення, статистичного аналізу, синтезу.

Результати та їх обговорення. Кількість військовослужбовців із числа учасників війни на сході України, які потребують дентальної імплантації, постійно зростає та становить насьогодні понад дві тисячі військовослужбовців.

Відповідно виникає протиріччя між спроможністю системи здійснювати лікування пацієнтів із вторинною адентією та кількістю військовослужбовців, які потребують лікування. Для вирішення цього протиріччя необхідно розроблення рекомендацій із підвищення ефективності системи.
Нами проаналізовано порядок комплексного лікування пацієнтів і комплексні показники кількості військовослужбовців, яким проведено лікування за розробленою класифікацією.

Порядок комплексного лікування пацієнтів із вторинною адентією (рис. 1) включає три послідовних етапи: діагностичний, хірургічний, ортопедичний. Зазначені етапи пов'язані між собою, але відрізняються за показником тривалості в часі $[12,13,14]$.

Від ефективності першого, діагностичного, етапу залежить кінцевий результат. На цьому етапі здійснюються заходи про виявлення інформації щодо дефектів жувально-мовного апарату конкретного військовослужбовця та відбір військовослужбовців, які потребують зубного протезування з використанням дентальної імплантації. До основних заходів відносили: зняття зліпків зубів; комп’ютерну томограму; телерентгенограму; фотопротокол; лицеву естетику. На цьому ж етапі проводилося загальноклінічне обстеження всіх пацієнтів, ортопантомографія. Деяким пацієнтам, за показами, проведено конусну комп’ютерну томографію.

Результатом етапу діагностики має бути план лікування із визначенням особливостей конкретного військовослужбовця та можливостей його лікування.

Хірургічний етап характеризується початком хірургічного втручання на якому проводяться такі заходи: анестезія, розріз ясен, підготовка кісткового ложа та встановлення імплантату, остеоінтеграція імплантату розкриття імплантату та встановлення формувача ясен. При цьому, деяким пацієнтам додатково проводили остеопластичні хірургічні маніпуляції з використанням остеотропних матеріалів. Усім пацієнтам — контрольну ортопантомографію. Результатом хірургічного етапу є встановлення імплантатів і правильне формування м'яких тканей ясен.

Ортопедичний, останній етап, характеризується зняттям зліпків після повного формування тканей протезного ложа, виготовлення запланованої протезної конструкції та її встановлення військовослужбовцю. Заміщення дефектів зубів у військовослужбовців здійснювали металокерамічними ортопедичними конструкціями з опорою на встановлені дентальні імплантати.

Зазначені етапи $є$ різними за тривалістю їх проведення. Найбільш складний - другий етап, 


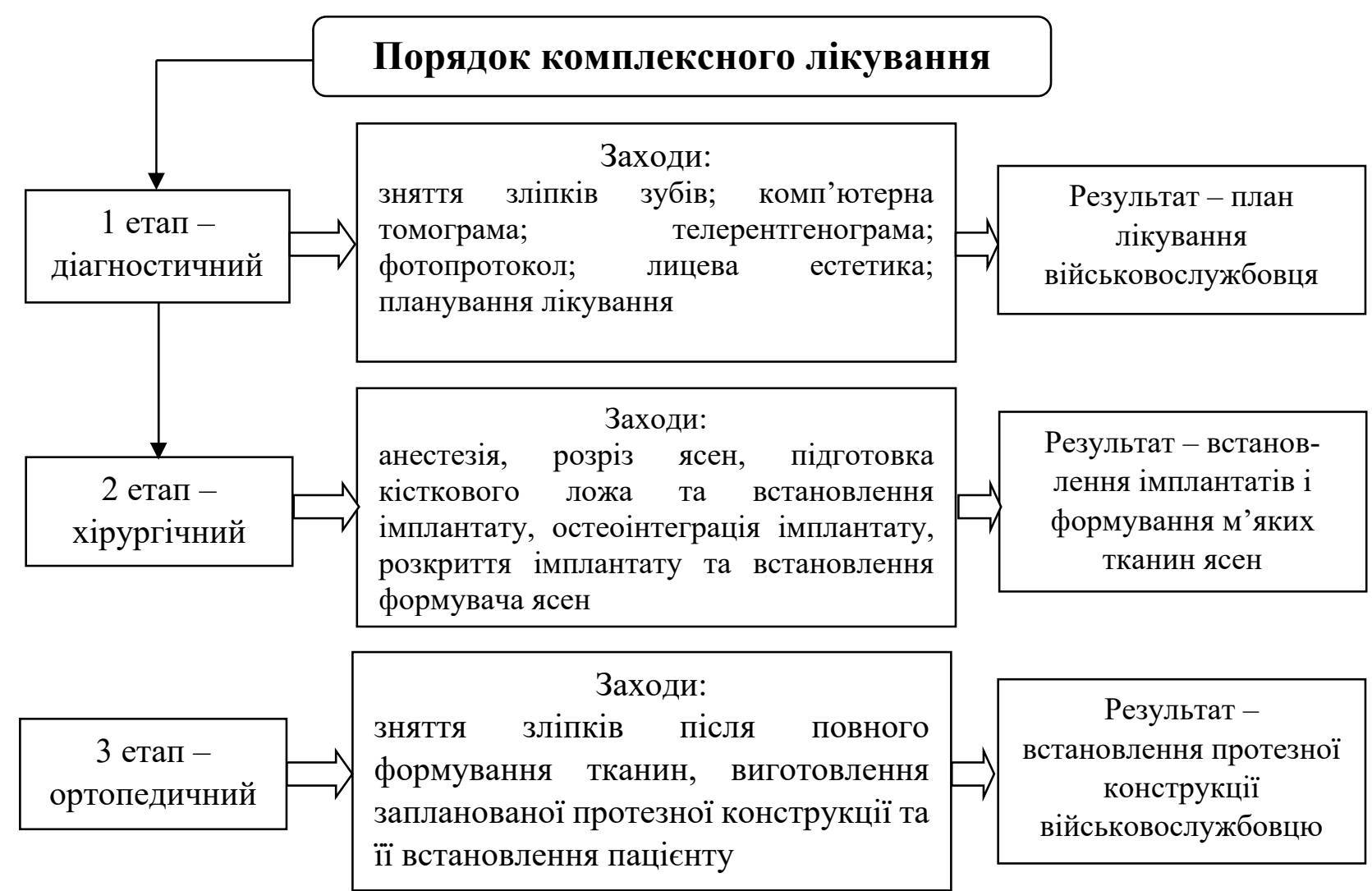

Рис. 1. Порядок комплексного лікування пацієнтів із вторинною адентією

тривалість якого може досягати до 6 місяців. Важливим аспектом являється ефективна робота 3 реалізації заходів, що залежить від факторів професійності спеціалістів, технологій, які застосовуються, та власне здатності організму військовослужбовця щодо його відновлення.

Лікування проводили військовослужбовцям із різними дефектами зубних рядів. Особливої уваги потребують пацієнти з повною адентією. Таким пацієнтам виготовлення незнімних ортопедичних конструкцій можливе лише при проведенні дентальної імплантації [15].

Для аналізу кількісного складу військовослужбовців, які потребують лікування, розроблено структурну класифікацію показників за групами військовослужбовців 3С України, які потребують дентальної імплантації. В основу зазначеної класифікації покладено розподіл військовослужбовців за соціальними (C) та клінічними (K) параметрами, а саме:

- за соціальними параметрами визначено групи:

I C — військовослужбовці з наслідками бойових ушкоджень щелепно-лицевої ділянки;
II C - військовослужбовці, які отримали бойові поранення інших анатомічних ділянок;

III C — інші військовослужбовці; - за клінічними параметрами:

I K — військовослужбовці 3 вторинною адентією, заміщення дефектів у яких незнімними ортопедичними конструкціями можливе лише при використанні дентальної імплантації;

II K - військовослужбовці 3 вторинною адентією, заміщення дефектів у яких незнімними конструкціями можливе як класичними мостоподібними протезами, так і при використанні дентальної імплантації (метод вибору);

III K — військовослужбовці з вторинною адентією, проведення дентальної імплантації у яких можливе лише після проведення додаткових передімплантаційних кістково-пластичних утручань.

Аналіз результатів кількісного складу військовослужбовців, які потребують лікування за обраною 
класифікацією дозволив визначити, що в більшості випадків причиною втрати зубів у військовослужбовців за період із 2015 по 2019 роки є низький рівень їх стоматологічного здоров'я. Лише в 3,7 \% причиною вторинної адентії військовослужбовців стали травми, отримані ними в бою або при перебуванні в полоні.

Всім пацієнтам проведено дентальну імплантацію в залежності від конкретної клінічної ситуації. У подальшому, їм проведено відновлення цілісності зубних рядів за допомогою металокерамічних ортопедичних конструкцій.

Лікування проводили військовослужбовцям із різними дефектами зубних рядів. Особливої уваги потребували військовослужбовці з повною адентією, яким виготовлення незнімних ортопедичних конструкцій можливе лише при проведенні дентальної імплантації.

Аналіз показників соціальних параметрів за обраний період наведено на рис. 2, 3.

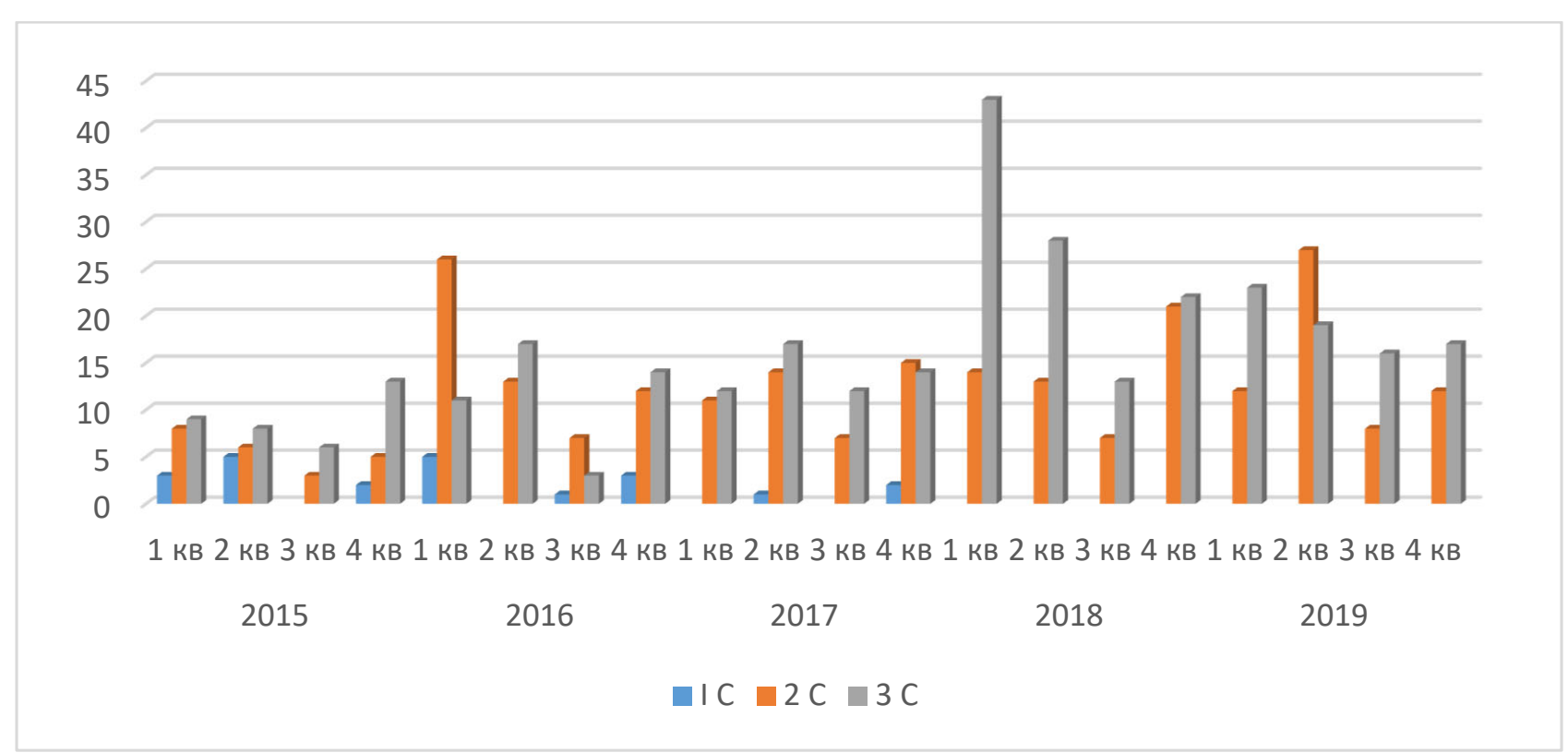

Рис. 2. Розподіл показників за роками за соціальними параметрами

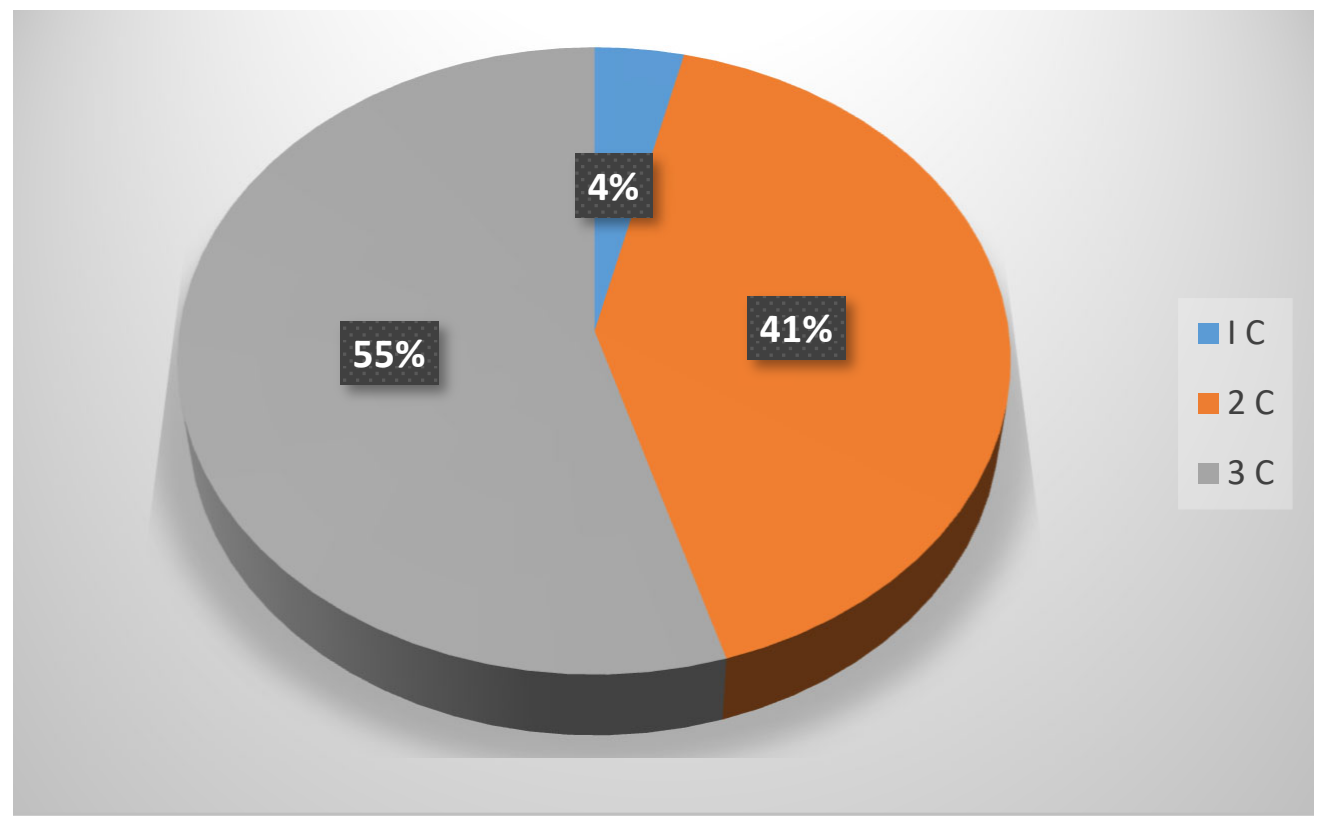

Рис. 3. Розподіл показників груп соціальних параметрів за період оцінювання 
Найбільша кількість військовослужбовців, які отримали поранення інших анатомічних ділянок і потребували лікування різних дефектів зубних рядів спостерігалась у першому кварталі 2016 року, при цьому найбільша кількість інших військовослужбовців - у першому та другому кварталі 2018 року (рис. 2). Слід зазначити, що лікування військовослужбовців, які отримали поранення інших анатомічних ділянок і потребували лікування різних дефектів зубних рядів, проводилось комплексно.
За обраний період найбільша кількість інших військовослужбовців, які отримали допомогу під час лікування різних дефектів зубних рядів, становила - 55 \%, а військовослужбовців, які отримали поранення інших анатомічних ділянок і потребували лікування різних дефектів зубних рядів - 41 \%.

Аналіз показників кількості військовослужбовців, які отримали допомогу під час лікування різних дефектів зубних рядів, за клінічними параметрами за обраний період наведено на рис. 4, 5.

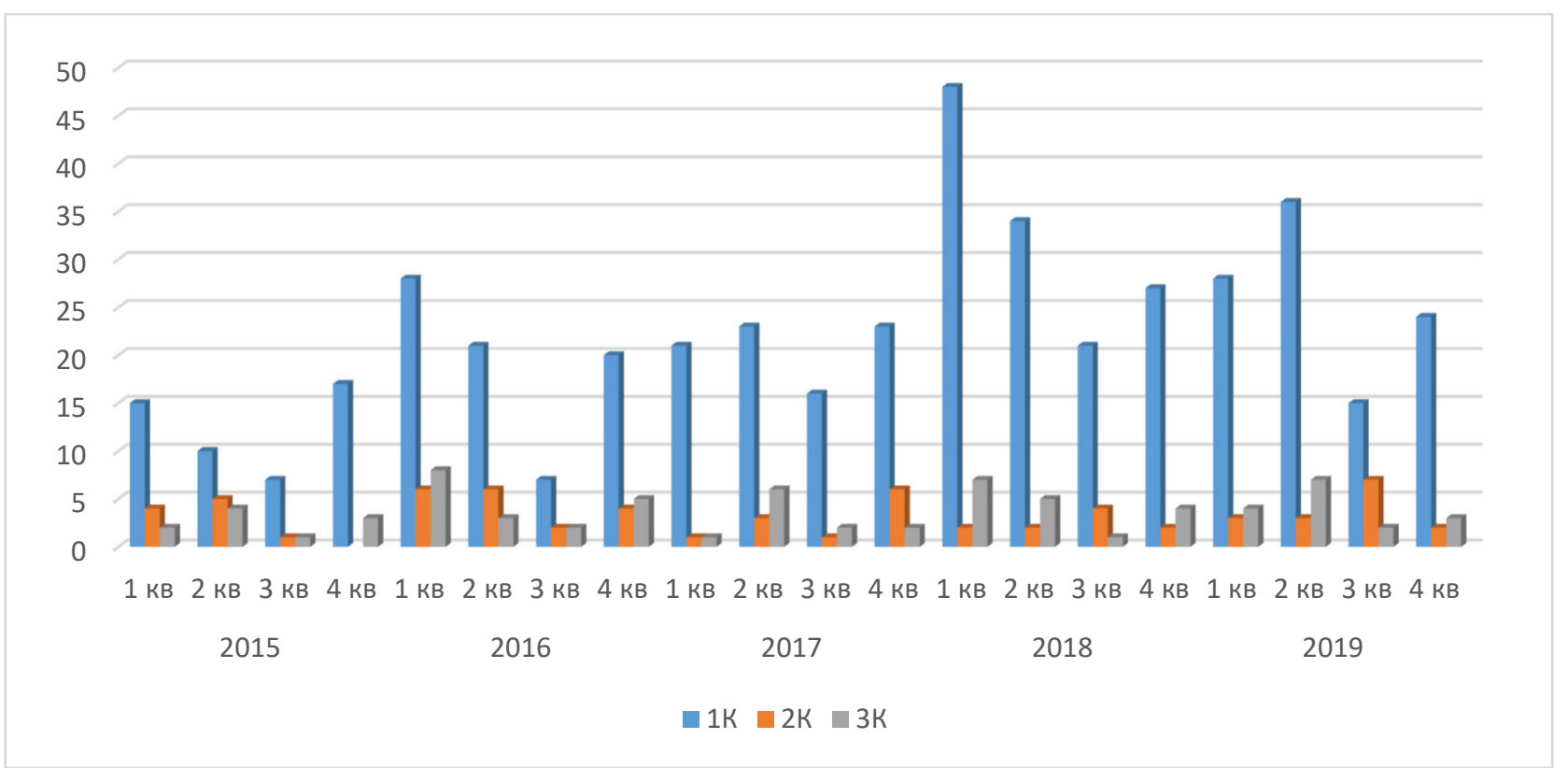

Рис. 4. Розподіл показників клінічних параметрів за роками

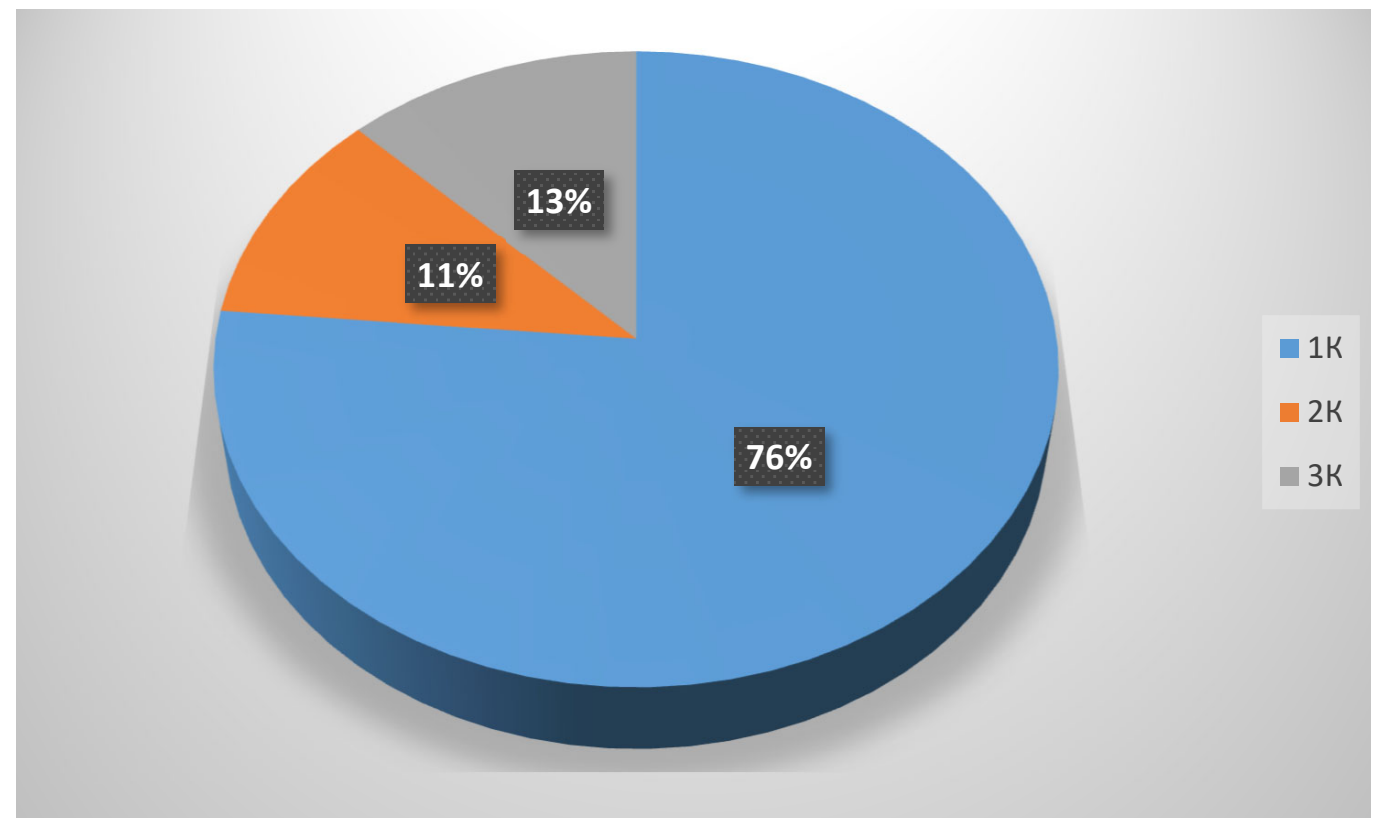

Рис. 5. Розподіл показників за групами клінічних параметрів 
За клінічними параметрами допомоги потребували найбільша кількість військовослужбовців із вторинною адентією, заміщення дефектів у яких незнімними ортопедичними конструкціями можливе лише при використанні дентальної імплантації (2018-2019 роки), що свідчить про низький рівень проведення лікарських оглядів у попередні роки (рис. 4).

Найбільша кількість військовослужбовців із вторинною адентією, заміщення дефектів у яких незнімними ортопедичними конструкціями, можливе лише при використанні дентальної імплантації складає за обраний період оцінювання 76 \%, що свідчить про пріоритетність розвитку даного напряму лікування.

Висновки. Розглянуто порядок комплексного лікування дентальної імплантації у військовослужбовців із вторинною адентією, а також показники кількості військовослужбовців, яким проведено лікування із використанням запропонованої класифікації. Визначено, що відновлення функції жування, що виникла внаслідок втрати зубів, $є$ актуальною проблемою стоматології. Ефективним методом лікування таких пацієнтів являється дентальна імплантація [15]. Результати дослідження дозволили узагальнити та обгрунтувати рекомендації щодо лікування військовслужбовців із різними дефектами зубних рядів:

1) для підвищення ефективності лікування слід уточнити заходи, що розробляються на діагностичному етапі порядку комплексного лікування 3 урахуванням розвитку технологій і засобів, які використовуються під час лікування;

\section{Література.}

1. 1. Bajaj A. Military dentistry: Duty Calls / Bajaj A. // Vital. - 2004. - № 1. - P. 27-30.

2. Impact of dental emergencies on combat readiness in Croatian Army / Brajdić D., Skec V., Macan J. S., Prgomet J., Macan D. // Acta Med Croatica. - 2006. № 60 (4). - P. 341-345.

3. Immediate functional loading of TiOblast dental implants in full-arch edentulous maxillae: a 3-year prospective study / Collaert B., De Bruyn H. // Clin Oral Implants Res. - 2008. - № 19 (12). - P. 1254-1260.

4. Combined gunshot wounds injuries maxillofacial area in the area of anti-terrorist operation in the East of Ukraine. Tactics of treatment / Fedirko I. V., Kozlovskyi S. M., Shmidt P. A. // Nauka i praktyka. - 2017. № 1-2. - P. 51-57.
2) враховувати на діагностичному етапі оцінювання дефекти мовного апарату та планувати заходи щодо його покращення;

3) через те, що частка бойових поранень щелепно-лицевої ділянки в загальній структурі санітарних втрат серед українських військовослужбовців на сході України складає близько 6 \%, дентальну імплантацію доцільно проводити в військових клініках (Role 4 за стандартами HATO), що мають підготовлений медичний персонал і спеціальне діагностичне та лікувальне обладнання;

4) для прогнозування щільності потоку військовослужбовців і плануванні їх лікування слід ураховувати розроблену класифікацію показів до дентальної імплантації українських військовослужбовців і результати їі аналізу;

5) використовувати інформаційно-аналітичні системи для автоматизації процесів лікування на всіх етапах комплексного лікування.

Пропозиції щодо подальших досліджень. У подальших дослідженнях доцільно розглянути проблеми оптимізації часу для комплексного лікування військовослужбовців на всіх етапах, впровадження інформаційно-аналітичних систем у діяльність медичного закладу, а також механізм комплексного лікування військовослужбовців, які отримали інші поранення та потребують дентальної імплантації.

5. Groves R. R. Dental fitness classification in the Canadian forces / Groves R. R. // Military Medicine. 2008. - Vol. 173 (1). - P. 18-22.

6. Dental caries experience in a young adult military population / Hopcraft M., Morgan M. // Aust Dent J. 2003. - Vol. 48 (2). - P. 125-129.

7. Kovalenko V. V. Special features of the treatment of the contemporary bullet injuries of the maxillofacial region / Kovalenko V. V. // Likars'ka Sprava. - 2017. № 1-2. - P. 168-174.

8. Status of dental care for military personnel in the area of anti-terrorist operation in the East of Ukraine / Likhota A. M., Kovalenko V. V., Liczichin M. Z., Fedirko I. V. // Viyskova medytsyna Ukraiiny. - 2015. - Vol. 1 (15). - P. 30-35. 
9. Dental implantation in the complex of treatment of Military Personnel with secondary adentia / Likhota A. M., Kovalenko V. V. // Problemy vijskovoyi ochorony zdorovja. - 2014. - Vol. 41. - P. 262-269.

10. Status and prospects of development of military dentistry in Ukraine / Lyshchyshyn M. Z., Kovalenko V. V. // Medicni perspektivi. - 2020. - Vol. 25 (1). - P. 9-17.

11. Analysis of Fixed Prosthesis Using Implants with their Immediate Loading in Elderly Patients with Complete Loss of Teeth on the Lower Jaw / Makeev V. F., Uhryn M. M., Zablotska O. Y. // Novyny stomatologii. - 2016. - Vol. 2 (87). - P. 8-19.

12. Rehabilitation of a gunshot wound with dental implants / Sharma M. C., Swamy M. M. // Med J Armed Forces India. - 2015. - Vol. 71 (1). - P. 160-162.

\section{References.}

1. Bajaj, A. (2004). Military dentistry: Duty Calls. Vital, 1, 27-30.

2. Brajdić, D., Skec, V., Macan, J. S., Prgomet, J., Macan D. (2006). Impact of dental emergencies on combat readiness in Croatian Army. Acta Med Croatica, 60 (4), 341-345.

3. Collaert, B., De Bruyn, H. (2008). Immediate functional loading of TiOblast dental implants in full-arch edentulous maxillae: a 3-year prospective study. Clin Oral Implants Res, 19 (12), 1254-1260.

4. Fedirko, I. V., Kozlovskyi, S. M., Shmidt, P. A. (2017). Combined gunshot wounds injuries maxillofacial area in the area of anti-terrorist operation in the East of Ukraine. Tactics of treatment. Nauka i praktyka, 1-2, 51-57.

5. Groves, R. R. (2008). Dental fitness classification in the Canadian forces. Military Medicine, 173 (1), 18-22.

6. Hopcraft, M., Morgan, M. (2003). Dental caries experience in a young adult military population. Aust Dent J, 48 (2), 125-129.

7. Kovalenko, V. V. (2017). Special features of the treatment of the contemporary bullet injuries of the maxillofacial region. Likars'ka Sprava, 1-2, 168-174.

8. Likhota, A. M., Kovalenko, V. V., Liczichin, M. Z., Fedirko, I. V. (2015). Status of dental care for military personnel in the area of anti-terrorist operation in the East of Ukraine. Viyskova medytsyna Ukraiiny, 1 (15), 30-35.
13. Surgical dental treatment for military personnel: where and when?-a case report / Stoetzer M., Schmidt R., Gellrich N. C., von See C. // Mil Med. - 2014. - Vol. 179 (11). - P. 1401-1403.

14. Risk of Dental Disease Non-Battle Injuries and Severity of Dental Disease in Deployed U.S. / Wojcik B. E., Szeszel-Fedorowicz W., Humphrey R. J. et. al. // Army Personnel. Mil. Med. - 2014. - Vol. 180. - P. 570-577.

15. Основи законодавства України про охорону здоров’я. Закон України від 19 листопада 1992 року № 2801-XII (зі змінами). - Режим доступу: https://zakon.rada.gov.ua/.

9. Likhota, A. M., Kovalenko, V. V. (2014). Dental implantation in the complex of treatment of Military Personnel with secondary adentia. Problemy vijskovoyi ochorony zdorovja, 41, 262-269.

10. Lyshchyshyn, M. Z., Kovalenko, V. V. (2020). Status and prospects of development of military dentistry in Ukraine. Medicni perspektivi, 25 (1), 9-17.

11. Makeev, V. F., Uhryn, M. M., Zablotska, O. Y. (2016). Analysis of Fixed Prosthesis Using Implants with their Immediate Loading in Elderly Patients with Complete Loss of Teeth on the Lower Jaw. Novyny stomatologii, 2 (87), 8-19.

12. Sharma, M. C., Swamy, M. M. (2015). Rehabilitation of a gunshot wound with dental implants. Med J Armed Forces India, 71 (1), 160-162.

13. Stoetzer, M., Schmidt, R., Gellrich, N. C., von See C. (2014). Surgical dental treatment for military personnel: where and when?-a case report. Mil Med, 179 (11), 1401-1403.

14. Wojcik, B. E., Szeszel-Fedorowicz, W., Humphrey, R. J. et. al. (2014). Risk of Dental Disease Non-Battle Injuries and Severity of Dental Disease in Deployed U.S. Army Personnel. Mil. Med, 180, 57-577.

15. Osnovy zakonodavstva Ukrayiny pro okhoronu zdorov"ya. - Zakon Ukrayiny vid 19 lystopada 1992 року № 2801-XII. [Fundamentals of Ukrainian legislation on health care]. Retrieved from: https://zakon.rada.gov.ua/. 